\title{
A Study of Some Aspects of Dylan Thomas's Poetic Style
}

\author{
1Ch. Nagaraju, ${ }^{2}$ Prof. A. Hari Prasanna, ${ }^{3}$ S. Peter \\ ${ }^{1,3}$ Assistant professor, Dept. of Science and Humanities, NBKRIST, Vidyanagar, SPSR Nellore Dt. India. \\ ${ }^{2}$ Professor, Dept. of English, S.V.University, Tirupathi, Chittoor Dt, India
}

\begin{abstract}
Thomas claimed that his poetry was "the record of my individual struggle from darkness toward some measure of light.... To be stripped of darkness is to be clean, to strip of darkness is to make clean." He also wrote that his poems "with all their crudities, doubts, and confusions, are written for the love of man and in praise of God, and I'd be a damned fool if they weren't." Passionate and intense, vivid and violent, Thomas wrote that he became a poet because "I had fallen in love with words." His sense of the richness and variety and flexibility of the English language shines through all of his work. Dylan Thomas uses symbols and images of nature to express how he feels towards death and childhood. He says that images are used to create a feeling of love towards life. Despite Dylan Thomas's obscure images, he expresses a clear message of religious devotion in many of his poems. The style of Dylan Thomas is an opaque poetic style which Thomas used to perfection. He possessed tremendous talent and was blessed with immense gifts that made him a professional success at a relatively young age.
\end{abstract}

Key words: obscurity, riddles, pseudo-drama, vocabulary and ambiguity

\section{Introduction}

Dylan Thomas is one of the writers who has often been associated with Welsh literature and culture in the last sixty years. He is possibly the most notable Welsh author. Fortunately, it is mainly his literary work, and not his tumultuous lifestyle, that is still associated with him. The analysis of some of his poems mirrors his sincere relationship to Wales.

Dylan Thomas was born in Swansea, Wales, in 1914. After he left school at the age of sixteen, he started working as a journalist in Swansea. In 1937, he married Caitlin MacNamara who gave birth to three children. These circumstances indicate a typical British, conservative and straightforward approach to family life. However, Dylan started drinking heavily, and Caitlin is rumoured to have had several extramarital affairs, even with colleagues and friends of her husband. Having moved to London, alcohol and indulgence were expensive for the young family, so they could not cover their costs anymore. Thus, in 1950, Thomas announced that he would emigrate to the United States because he thought he would be paid better there than in England. He settled in New York where he recited his works, and was profoundly admired. Nevertheless, the money he earned was spent on alcohol, which led his marriage with Caitlin into a serious crisis. On November 9, 1953, he died after a heavy drinking binge in a Manhattan hotel, at the age of 39. Later, Thomas's body was brought "home" to Wales. He was buried in the churchyard of Laugharne.

Dylan Thomas was influenced in his writing by the Romantic Movement from the beginning of the nineteenth century, and this can be seen in a number of his best works. Dylan Thomas uses symbols and images of nature to express how he feels towards death and childhood. He says that images are used to create a feeling of love towards life. Despite Dylan Thomas' often obscure images, he expresses a clear message of religious devotion in many of his poems. He creates images that reflect God's connection with the earth and body. In "And death shall have no dominion," Thomas portrays the redemption of the soul in death, and the soul's liberation into harmony with nature and God. Thomas associates God with thunder, rainbows, and night only to remind us that he is even more present in a simple stone as he is in other great entities. Colour imagery is also there in some of his poems as he describes his happiness as a child. He explains his young days as being as "happy as the grass is green."

The style of Dylan Thomas is an opaque poetic style, which Thomas uses to perfection. It is used to describe the unusual and day-to-day activities. Dylan Thomas possessed tremendous talent and was blessed with immense gifts that made him a professional success at a relatively young age; however, his personal life was often disappointing.

Style is the dress of thought of the poet. The poet would strive to use the most appropriate devices for presenting his ideas. These devices may be the poet's own or derived from age old traditions. One poet's style may differ from that of another, or even bear similarities with each other based on the factors which have influenced them. Emerson asserts that "A man's style is his mind's voice". The style, therefore, indicates who the author is. 
The reader's efforts to draw out the meaning from his poems often met with futile ends. Even after much dissection, several of his poems remain still unreachable. As awkwardness becomes the style of Hemmingway, obscurity and ambiguity mark the style of Thomas.

\section{Obscurity}

Obscurity is one of the factors determining the reader's aesthetic experience. It requires major intellectual effort and calls for successive examinations of the poem, which do not necessarily follow the same order as that of elements of the text.

A good poem may be obscure in two ways: it may express an obscure thought or idea in relevantly obscure language; or it may express a simple thought or idea in obscure language- language not relevant to the thought of idea, but relevant to the poem as a whole. In the first case, an obscure thought cannot be made clear by rendering it simply; and though the words employed in this kind of poem may be readily intelligible and obviously relevant- nearly enough the right words- they are not much help as a guide to its meaning. The division can be made in another, and convenient way by saying that either the matter of the manner of a poem may be obscure; sometimes, but rarely, both. Obscurity occurs when the reader is not up to the writer.

The reading of the poem 'When once the twilight locks no longer' indicates that the procedures which underlie the comprehension of clear texts will not suffice in the case of Thomas's obscure poem. It is assume that anyone reading these lines will have encountered problems in comprehending the poem. In this instance, the obscurity, being an essential principle of Thomas's early poetry, is intentional. However, obscurity is not invariably intentional; a text written in the 18th century, for example, readable by contemporaries of the poet, could cause difficulties for modern readers who lack contextual references. Difficulties here are not the poet's intention.

The purpose of a poem is to communicate the ideas of the author to the reader. When the poem fails in this area, the primary purpose itself gets defeated. But Thomas, a committed craftsman did not deviate himself from his respectable task in spite of the apparent obscurity of his poetic style. According to him all his poems are written to be understood, but he admits that he is deliberately obscure. In his deliberate obscurity he is reminiscent of the welsh bards.

The Welsh bards chose to be obscure to prove themselves greater than ordinary folk, and to assert their superiority over other bards and to show off their wide learning and skill and their high calling. Leaving out all punctuations leading to obscurity can be seen in his poem 'Refusal to Mourn the Death, by Fire, of a Child in London'.

Never until the mankind making

Bird beast and flower

Fathering and all humbling darkness

Tells with silence the last light breaking

And the still hour

Is come of the sea tumbling in harness

In some of his statements Thomas gives the reasons for his being incoherence. His view is that his poems should be understood by the reader, by pondering on it and not by grasping the meaning just by one look at it. The reader can think on the poem only when it is difficult to understand.

Elder Alson does not regard obscurity as a fault but as a poetic device to draw the attention of the reader. He observes the difficulty of Thomas's poems stemming out of his willfulness.

Thomas resorted to the use of discordant images and words that bewildered the readers leading to obscurity. The duty of the poet is to purify the dialect for communicating purpose. Communication is the ultimate criterion of any art. But Geoffrey Johnson in his review of Thomas's collected poems says Thomas's means of communication are almost always ineffective. Instead of purifying the dialect he did in all his spheres to obscure the dialect, leading to obscurity.

Thomas as a poet with welsh spirit, using a language peculiar to him, renders the meaning demanding emphatic hard work fro the hearer. Here Thomas deviates from the surrealists whom he is often being associated with. William York Tindall has made an exhaustive study of Thomas's Poetry along with his students. He tells how they wrought clarity of meaning after much hard work. It is attained only when the reader as Thomas says thinks and feels the poem.

W. Empson compares Thomas's poems to school problem papers since both need working out, are thrilling and interesting and keep mind occupied and enthusiastic till the answer is attained. Though the answer is not wrought still one can feel there is something to be attained in the problem. To Empson Thomas's poems and school problems papers were equally inexhaustible.

Dylan Thomas was obsessed with words - with their sound and rhythm and especially with their possibilities for multiple meanings. This richness of meaning, an often illogical and revolutionary syntax, and catalogues of cosmic and sexual imagery render Thomas's early poetry original and difficult. 
In a letter to Glyn Jones, Thomas wrote: "My own obscurity is quite an unfashionable one, based, as it is, on a preconceived symbolism derived from the cosmic significance of the human anatomy."

\section{Riddles:}

There is another important aspect of Thomas's poetry- they are often riddle- like. This may be an outcome of his use of idiom, phrase, imagery, comparison and techniques of depiction. In the Welsh bardic poetry also there were 'dyfalu' which are called 'comparisons' in English. The bards often drew them from nature. The riddle gets solved only after considerable effort to understand it. A description of the wind in the old Welsh poetry is as follows:

Guess who it is - created before the Flood;

A creature strong, without flesh, without bone,

It is evil, it is good, it is yonder, it is here....

It is moist, it is dry, it comes often times.

Thomas's poems cannot be compared on this level. But his use of comparisons makes his poems look like a riddle. Half-said things were dear to the Welsh bards. The same was the case with Thomas. This technique of depiction is influenced partly by the unusual play of his imagination producing a confusing variety of images. Very often it is difficult to decide who the speaker is or who the listener. The idea and the circumstances also are equally vague. Elder olson calls this 'circumstantial ambiguity'. In his use of 'circumstantial ambiguity' and 'pseudo-drama' Thomas's poems are often riddles.

\section{Pseudo-drama}

Pseudo- drama is the use of dialogue to suggest the action as interplay among several persons which are not distinct. In other words, pseudo-drama is the use of dramatic devices to represent an action as if dramatic which originally is not dramatic. It creates often vividness, concreteness, intensity and elevation of thought in his poetry.

'If my head hurt a hair's foot

Pack back the downed bone. If the unpricked ball of my breath

Bump on a spout let the bubbles jump out.

Sooner drop with the worm of the ropes round my throat

Than bully ill love in the clouted scene.

Thomas's use of pseudo-drama serves many purposes to attain economy, to express the thought in a lively, forcible and impressive way. Elder Olson observes that 'the device of pseudo-drama has many uses; and vividness where these otherwise would be impossible; it can heighten the contrast between two opposing points of view, or between conflicting motives and desires; it can produce a striking degree of economy as well.

\section{Imagery}

Another cause for Thomas's obscurity is discordant and confliction images to Thomas. A poem is a constant building up and breaking down of the images which come out of the centre - 'a host of images'. Thomas himself explains his dialectical method in a letter to Henry Treece as follows:

A poem by myself needs a host of images, because its centre is a host of images. I make one image....let it breed another, let that image contradict the first, make of the third image breed out of the other two together, a forth contradictory image, and let them all, within my imposed formal limits, conflicts. Each image holds within the seed of its own destruction, and my dialectical method, as I understood it, is a constant building up and breaking down of the images that come out of the central seed, which is itself destructive and constructive at the same time.

Thomas wanted his poems to be understood- the poems that demand hard work on the part of reader. But for most of the readers his poems with conflicting images always remain obscure. Talking about Thomas's images Karl Shapiro points outs that "Thomas's imagination, which is sometimes fantastic, works hard to dredge up the images of fantasy and dreams. Very often the process fails and we are left with heaps of grotesque im ages hat add up to nothing.

'Light breaks where no sun shines' shows the images of the womb, the body and the mind. Beautiful images are wrought by comparing the man with universe. Still there is incoherence of thought because of the images. Dawn breaks behind the eyes;

From poles of skull and toe the windy blood

Slides like a sea;

Nor fenced, nor staked, the gushers of the sky

Spout to the rod

Divining in a smile the oil of tears. 
But for a careful reader, Thomas's poems with all their discordant images render meaning. Tindall detects the 'central seed' and meaning underneath the conflicting and confusing images by saying that 'deeply planted, to be sure, the sense is always there.. to him the poems were simple transactions between plain sense and a dialectical process of image, acting as sense's surrogate.

\section{Vocabulary}

The main difficulty in Thomas's poetry is the difficulty offered by his diction. Thomas's love for words manifested itself in accumulating and manipulating the words to achieve his artistic purpose marks his style. He bends the words to obtain metrical patterns and to convey the vigorous, forcible feelings of his turbulent soul. Whatever he purpose might have been, he is in love with words. He delights in the sound and shape of words. He himself admitted that he was more a user of words than a poet. Thomas states 'I am freak user of words, not a poet. That's really the truth. No self pity there'.

Just as the Welsh bards manipulated words, piling adjective upon adjective, making compound words, Thomas also used words in a manner which resulted in obscurity. This became more conspicuous in his later poetry. Here is an example of his verbosity.

Is corner-cast, breath's rag, Scrawled weed, a vain

And opium head, crow stalk, puffed, cut and blown

Or like the tide-looped breast not reefed again

Or rent ancestrally the roped sea-hymen,

And, pride is last, is like a child alone

By magnet winds to her blind mother drawn,

Bread and milk mansion in a toothless town.

The bending, breaking and compiling the language to attain artistic purpose goes back to Celtic literature. Thomas follows this device in his poetry. The words in his poetry were chosen from a variety of spheres but his conscientious careful craftsmanship selects and uses the words to achieve his poetic end. The devices range from simple words to metrical patterns which he calls them as his 'technical paraphernalia'.

\section{Conclusion}

Dylan Thomas is associated with innocence because there was a childlike quality about him which made him look untouched by the corruption of the world around him. John Malcolm Brinin pays Thomas compliments of high order in the course of his analysis of the impact of the poet on American public. Karl Shapiro says 'in an age when poets are supposed to be born old, everyone looked upon Thomas as the last of the young poets. When he died, it was as if there would never be any more youth in the world. His knowledge of Welsh accent, phrases and words that came to him through Welsh speaking friends and relatives had their influence on him. They must have shaped the sound patterns in his poetry.

\section{Acknowledgements}

I record a deep sense of gratitude to my Teacher and Research Supervisor Dr.A.Hari Prasanna, M.A.,M.Phil.,Ph.D., Professor, Department of English, S.V. University, Tirupathi. I am indebted to her for the concern, counsel and encouragement I have received from her both at personal and academic levels.

I also express my acknowledgement to the management, the Director and the H.O.D of Science and Humanities of N.B.K.R.I.S.T., Vidyanagar for their encouragement.

It is a real pleasure for me to express my indebtedness to my wife, my beloved mother and other family members for their care and encouragement.

I acknowledge the cooperation and assistance I have received from my friends and colleagues.

\section{Journals}

[1] Anderson, M. Robert. "Thoma's 'A Refusal to Mourn..."” The Explicator.

[2] Cox, C.B. "Dylan Thoma's 'Fern Hill' " The critical Quarterly. Vol.1, No.2

[3] Joshi, Neeta. "Influence of the Welsh Bardic Tradition in the Poetry of Dylan (1990).

[4] Mckay, D.F. “Aspects of Energy in the Poetry of Dylan Thomas and Sylvia (Spring, 1974).

[5] Parshall, F. Peter "Thomas's The Force that Through the Green Fuse Drives the (April, 1971).

[6] Press, John. "Dylan Thomas: A Refusal to Mourn...., Fern Hill, over Sir John's (September, 1967 ).

[7] Smith, A.J. “Ambiguity as Poetic Shift (Analysis of Dylan Thomas's 'Our No.1 (Spring, 1962).

[8] Terrel, F. Caroll. "Thomas's Over sir John's Hill.” The Explicator. Vol.38,

Vol.38, No.4 (Summer, 1980).

(Summer, 1959).

Thomas" Punjab University Research Bulletin. 21 Plath" The Critical Quarterly. Vol.16, No.1 Flower". The Explicator. Vol.29, No.8 Hill." Notes on Literature. No.74, Eunuch Dreams').” The Critical Quarterly. Vol.4, No.4 (Summer, 1980). 
[10] Willis, Roger. "Dylan Thomas: Under Milk Wood." Notes on Literature.

No.102 (January, 1970).

[11] Young, Allan. "Image as Structure: Dylan Thomas and Poetic Meaning." The

Critical Quarterly. Vol. 17, No.4 (Winter 1975).

\section{Books}

[12]

[13]

$[14]$

[15]

[16]

[17]

[18]

[19]

Brinnin, Harry, ed. A Guide to Twentieth Century Literature in English. London: Methuen, 1983.

Cecil, Lord David, ed. The Oxford Book of Christian Verse. Oxford: Clarendon, 1940.

Cox, C.B, ed. Dylan Thomas: A Collection of Critical Essays. Englewood Cliffs : Prentice, 1966.

Davies, Aneririn Talfan. Dylan: Druid of the Broken Body. Swansea: Salisbury, 1977.

Davies, Walford. 'Dylan Thomas', Arts : A Third Course Twentieth Century Poetry. Unit 26, Keynes: The Open University Press, 1979.

Deutsch, Babette. Poetry in Our Time. New York: Columbia University Press, 1956.

Eliot, T.S. Selected Essays. London: Faber, 1951.

Essays Ancient and Modern. London: Faber \& Faber, 1949.

Evans, B. Ifor. A Short History of English Literature. Great Britain: Penguin Books, 1958

Ferris, Paul. Dylan Thomas. London : Hodder and Stonghton, 1978.

Fitzgibbon, Constantine. The Life of Dylan Thomas. London: J.M. Dent, 1965.

James, Daniel. My Friend Dylan Thomas. London: J.M. Dent, 1977.

Jones, Gwyn. The Oxford Book of Welsh Verse in English. New York: Oxford University Press, 1977.

Kidder, M. Rushworth. Dylan Thomas: The Country of the Spirit. U.S.A: Princeton University Press, 1973.

Kleinman, H.H. The Religious Sonnets of Dylan Thomas: A Study in Imagery and Meaning. Los Angeles: University of California Press, 1963.

Lodge, David. The Modes of Modern Writing. London : Edward Arnold, 1971.

Monro, Harolid. Twentieth Century Poetry. London: Chatto and Windus, 1950.

Moynihan, T. William. The Craft and Art of Dylan Thomas. New York : Cornell University Press, 1966

Olson, Elder. The Poetry of Dylan Thomas. Chicago: University of Chicago, 1954.

Parry, Thomas. A History of Welsh Literature. Trans. Idris Bell, London: Oxford University Press, 1955.

Pater, Walter. Appreciations. London: Macmillan, 1944.

Singh, Brijraj, ed. Five Seventeenth Century Poets. New Delhi : OUP, 1992.

Spender, Stephen. Since 1939, Drama, The Novel Poetry, Prose Literature. London : Longman, 1959.

Tedlock, E.W, ed. Dylan Thomas: The Legend and the Poet. A Collection of Biographical and Critical Essays. London: William Heinemann, 1960.

Trindall, W.Y. A Reader's Guide to Dylan Thomas. New York: Ferras and Straus Company, 1962.

Traherne, Thomas. Centuries of Meditations. London: Dertram Dobell, 1908.

Treece, Henry. Dylan Thomas : 'Dog Among the Fairies', Rev. ed. London: Ernest Benn, 1959. 